Article

\title{
Carsharing Services in Italy: Trends and Innovations
}

\author{
Lucia Rotaris
}

check for

updates

Citation: Rotaris, L. Carsharing Services in Italy: Trends and Innovations. Sustainability 2021, 13, 771. https://doi.org/10.3390/ su13020771

Received: 21 December 2020 Accepted: 11 January 2021 Published: 14 January 2021

Publisher's Note: MDPI stays neutral with regard to jurisdictional clai$\mathrm{ms}$ in published maps and institutional affiliations.

Copyright: $\odot 2021$ by the author. Licensee MDPI, Basel, Switzerland. This article is an open access article distributed under the terms and conditions of the Creative Commons Attribution (CC BY) license (https:// creativecommons.org/licenses/by/ $4.0 /)$.
Dipartimento di Scienze Economiche, Aziendali, Matematiche e Statistiche, University of Trieste, 34127 Trieste, Italy; lucia.rotaris@deams.units.it; Tel.: +39-040-558-7072

\begin{abstract}
Transport is a critical factor for social-economic development, however, its environmental footprint cannot be neglected and is increasing over time. New mobility services based on collaborative consumption, such as peer-to-peer carsharing, have been developed with the aim of improving accessibility and reducing the negative externalities produced by transport. However, in the literature, there are very few documents that analyze collaborative consumption in the transport sector. To shed light on this topic, we described the Italian carsharing market and explained how it has changed over time. Moreover, we studied the potentialities of peer-to-peer carsharing in a less densely populated Italian region on the basis of a survey we conducted through face-to-face interviews. We found that the main reason preventing its spread is that individuals are not yet aware of its existence. We also analyzed the motivations of those who would like to use it and of those who stated the opposite. Suggestions are presented on the strategies to be implemented to facilitate the adoption of the service for the benefit of both platform providers and local administrators.
\end{abstract}

Keywords: peer-to-peer carsharing; collaborative consumption; sustainable transport; contingent valuation; network effects

\section{Introduction}

Air pollution produced by anthropogenic activities including transport is a risk factor for human health and ecosystems. In 2013, the European Union established two objectives: to achieve full compliance with the legislation in force in the territory of the Union by 2020 and to achieve full compliance with the levels recommended by the World Health Organization by 2030 [1]. However, the 2020 report of the National System for Environmental Protection [2] shows that in Italy in 2019 both limit values and target values were largely exceeded, in particular with respect to particulate matter and ground-level ozone. Moreover, according to the 2020 report of the Italian Institute of Training and Research for Transport [3], the mobility demand in Italy is increasing. In the last three years, the number of trips per day has increased by $8 \%$, while the number of passengers ${ }^{*} \mathrm{~km}$ has increased by $14.3 \%$. Moreover, most journeys are made by car or scooter $(64 \%)$, and the pandemic crisis has further intensified the use of motorized private vehicles. Indeed, the Italian motorization rate is among the highest in Europe, and in 2019, it reached an all-time high: 65.6 for cars and 11.4 for scooters. Carsharing (CS) services could be a viable solution to the need of ensuring high accessibility levels while decreasing the negative externalities caused by the private use of motorized vehicles. The empirical evidence, in fact, proofs that CS helps to reduce car ownership [4-13], favors the joint use of shared vehicles and public transport [13], favors active transport [12] and reduces congestion, air pollution [14] and parking search times in urban centers $[15,16]$.

The history of CS in Italy is relatively recent compared to countries such as Switzerland, Germany, Austria and the Netherlands where CS has been offered since the 1980s. The launch of CS in Italy is traced back to 2001, when the Car Sharing Initiative (ICS), an association of municipalities supported and funded by the Ministry of the Environment, started promoting and supporting CS as a means toward sustainable urban mobility. The free-floating CS services arrived much later, in 2013, and from Milan, where they were 
initially offered, they quickly spread to the other largest Italian cities. CS is constantly evolving thanks to the innovations of the Information and Communications Technology sector, making the service more flexible and simple (location, booking, payment and opening of the vehicle are now generally done through the mobile phone) and, due to the changing preferences of consumers, more favorable toward using shared vehicles as an alternative to owning one. The studies focused on the supply and demand of CS in Italy are not numerous and do not report on how both the supply and the demand for CS have changed over the last few years. The objective of this paper is twofold. On the one side, we update the description of the CS services offered in Italy. On the other side, we review the literature on peer-to-peer carsharing (P2PCS) and analyze its potential demand in Friuli-Venezia Giulia, a less densely inhabited Italian region. This research is further justified by the fact that there are very few studies on the motives for joining and for not willing to join a P2PCS and there are no studies analyzing this topic with specific reference to less densely inhabited areas. Managers and policy-makers will benefit from our research because it detects the psychological barriers preventing the P2PCS uptake in Italy and allows better designing segment-specific marketing activities and regulatory and fiscal policies aimed at fostering participation rates.

\section{Economics of Collaborative Consumption in the Carsharing Market}

\subsection{Economics of Collaborative Consumption}

Internet-based exchange markets and mediation platforms are shifting consumers from owing resources to sharing their consumption. Most resources, indeed, are underutilized since they are acquired to satisfy peak demand. Collaborative consumption enables the exploitation of idling capacity, the increase in resources' access and the reduction in investments, benefiting both resource owners and renters. This new consumption paradigm has transformed consumers into prosumers, individuals who consume and produce value for either self-consumption or consumption by others and can receive implicit or explicit incentives from organizations involved in the exchange [17].

Collaborative consumption is a special form of a two-sided market where an intermediary or a platform allows two sets of agents to interact reducing their transaction costs, with the peculiarity that owners and renters are peers. In one-sided markets, value moves from producers, facing the cost of production, to consumers, providing the revenues. In two-sided markets, instead, an intermediary incurs costs in order to serve both groups of agents and collect revenue from each group. Platforms such as Expedia are examples of standard business-to-consumer (B2C) two-sided markets, while Airbnb is an example of a peer-to-peer (P2P) two-sided market where the suppliers are not professionals nor have employees or established product lines. In fact, the distinctive characteristic of a collaborative consumption setting is that individuals belonging to each side of the market do not differ. Each user of the platform can be-and decides whether to be-an owner or a renter [18]. Within the collaborative consumption setting involving peers, an additional distinction could be made. One form of a P2P market is based on renting the resources among peers, and it is typically the case of carsharing services where the car ownership is not transferred to the peers renting the vehicle. Access-based consumption gives consumers the opportunity to have access to new and diverse products without the burden of ownership. It involves a transaction in which no transfer of ownership takes place. However, it involves different levels of market mediation, from for-profit (renting) to not-for-profit (pure sharing) [19]. Another form of a P2P market involves, instead, the redistribution of the ownership of the resources among peers; an example would be eBay through which the property rights of the resources are transferred from the owner selling the resource to a peer buying it. In both cases, there is a monetary transaction among the peers, but in the renting setting, the ownership of the resource is not transferred to the peer who acquires only the right to temporarily use it (Figure 1). The main motivations for participating in collaborative consumption are sustainability (helping others and the environment), enjoyment, reputation (since an individual can gain reputation among 
other people due to his/her sharing activities, and this reward can be a driver for active participation) and economic benefit (saving money and time) [20].

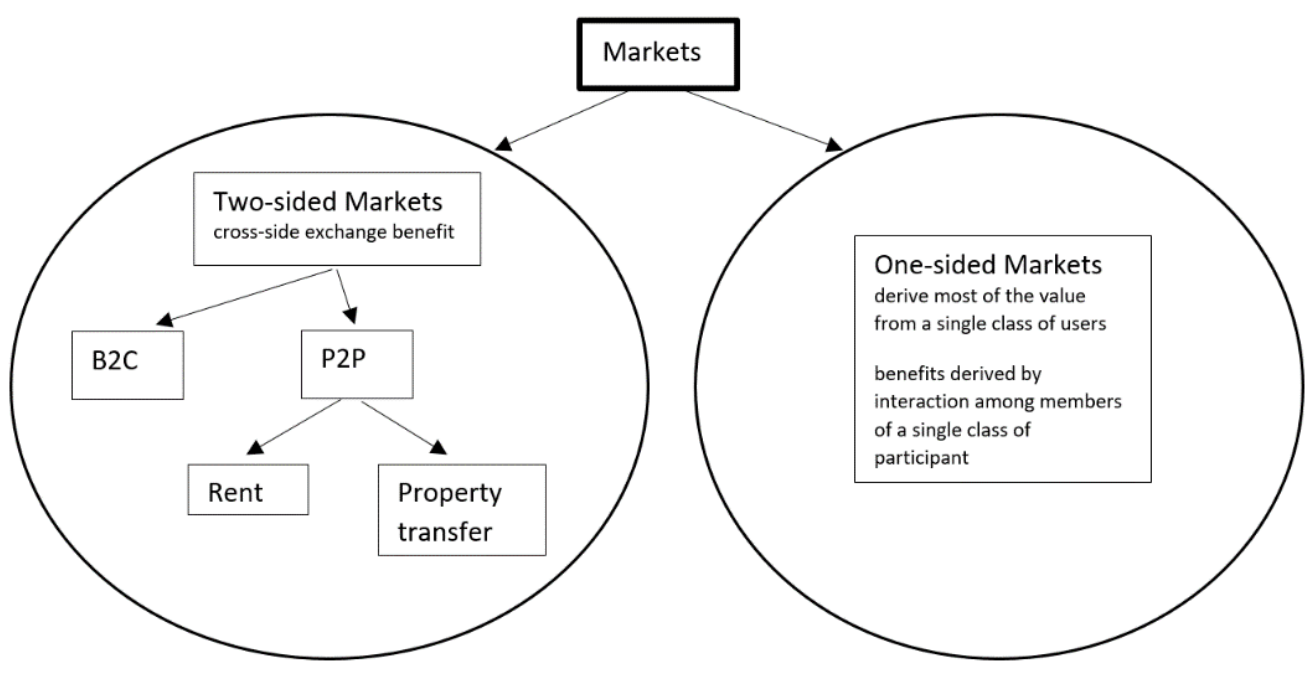

Figure 1. Market types.

As in a standard two-sided market, direct network externalities are not necessarily positive, since if the number of renters increases, with a fixed number of owners, the resources available to each renter reduce [21]. Cross-group externalities, instead, are positive since peers' utility increases when a new member of the other side of the market joins the network. The larger the number of owners willing to supply, for example, their cars through a carsharing platform, the larger the number of renters willing to subscribe to the platform, and vice versa [22]. However, differently from a standard two-sided market, having a too-large size of one of the two sides of the market creates an imbalance in the supply and the demand for the shared resource, reducing the utility of both owners and renters.

\subsection{Carsharing and Collaborative Consumption}

The most common types of two-sided markets offering carsharing services are:

1. The B2C round-trip: users must return the vehicle to the same place where they picked it up;

2. The B2C one-way station-based: vehicles can be returned to any of the parking spaces reserved for the service;

3. The B2C one-way free-floating: vehicles can be returned to any place within an area defined by the manager.

In all three cases, the owner of the vehicles is the service provider. These CS types are highly capital-intensive, as service providers have to invest in vehicle purchase and maintenance, in charging stations (if electric vehicles are used), in web interface and/or smartphone app for vehicle booking and in vehicle opening and monitoring technology [23]. To ensure the financial sustainability of the service, it is therefore essential to maximize the time the vehicles are used, designing the service and the rate levels that best suit the market served. Rates and characteristics of the service, including which types of vehicles should be rented (city cars vs. larger family cars; internal combustion vs. electric vehicles), must be constantly updated according to the demand needs and to the changing market conditions (entry of new competitors, changes of availability of public transport services, availability of new technologies).

Peer-to-peer carsharing (P2PCS) differs from business-to-consumer carsharing (B2CCS) since fleets are made only of personally owned cars. Car owners and renters share the vehicles through a platform where it is possible to book the car, post the characteristics of 
the car, of the car's owner and of the renter and pay the rental fee. A third-party company charges both owners and renters a percentage of the rental fee in order to carry out network operations and to provide liability and vehicle insurance. Start-up and operating costs are negligible compared to B2CCS because the platform operator does not have to buy the vehicle fleet nor to pay for its maintenance. This form of CS benefits both car owners and renters. More specifically car owners, typically having a spare car or a seldom-used primary car, list their vehicles on the platform and are compensated with payments that offset at least partially depreciation and maintenance costs. Car renters, who do not own a car or need specific vehicles for special occasions, can choose among a large variety of models, locations and prices. P2PCS is highly based on network effects, since car owners are more likely to list their vehicles if there is a large number of renters, while a large selection of cars, i.e., participating owners, is crucial to acquiring new renters and keeping old ones. Indeed, convenience (e.g., a car within walking distance) and choice (e.g., luxury/economy cars of different models and colors) are key factors for the demand side of the market. However, the platform operator needs to properly design and finance marketing and support activities to achieve the critical mass needed. Once the critical mass is reached, new users are acquired through word-of-mouth from existing users, and user satisfaction consequently increases.

\section{Literature Review on Collaborative Consumption in the Carsharing Market}

Although there are many studies on B2CCS, there are only a few scientific contributions shedding light on P2PCS. Among these, only a few papers analyze both the demand and the supply side of the market (Table 1), while most of the papers focus exclusively on one side of the market (Tables 2 and 3 ).

\subsection{Literature Analyzing Both the Demand and the Supply}

Ballús-Armet et al. [24] analyzed the preferences for CSP2P in San Francisco and Oakland (USA) finding that only $50 \%$ of respondents knew the characteristics of the service and that only $25 \%$ shared their car. With respect to car owners, those who used public transport more frequently and used their car less regularly were more likely to rent out their vehicle. The barriers preventing the use of the service were mainly linked to lack of trust and liability concerns. As regards the potential car renters, however, the results were more encouraging and indicated that $60 \%$ of the respondents living in San Francisco and $75 \%$ of the respondents living in Oakland would use the service as a less expensive and more flexible alternative to public transport and car ownership. Münzel et al. [25] analyzed whether characteristics and motives differ between B2C and P2P carsharing adopters. They conducted a survey in 2014 involving a sample of 1835 individuals representative of the Dutch population over the age of 18. They found that CS adopters had a higher educational attainment, used public transport services more frequently and were more environmentally conscious. They also found that P2P users were more cost-sensitive but less public-transport-oriented than B2C users and that P2P renters more frequently informally provided their car to friends and family. According to the empirical evidence reported by the authors, for $\mathrm{P} 2 \mathrm{P}$ car owners, trusting others was a more important factor than gaining extra income. Gaarsdal et al. [26] performed an online survey in 2017 involving 218 members of GoMore, a nationwide P2P carsharing network in Copenhagen (Denmark). They found that membership was higher among males, aged 30-34, having a high level of education. The main motivation of car owners for renting out their car was getting extra income and using their car more efficiently and, to a lesser extent, supporting environmental sustainability. The main motivation of renters for using the service was having more transport options, cost savings and, to a lesser extent, supporting environmental sustainability. Renters mostly used the service for visiting family and friends or for vacation. P2PCS substituted private car (42\%) or public transport services $(40 \%)$, allowing also trips that would not had been made without the CS service (15\%). 
Table 1. Papers analyzing both the demand and the supply.

\begin{tabular}{|c|c|c|c|}
\hline & Ballús-Armet 2014 [24] & Munzel et al. 2019 [25] & Gaarsdal et al. 2017 [26] \\
\hline Country & USA & The Netherlands & Denmark \\
\hline Year & 2013 & 2014 & 2017 \\
\hline Data collection & intercept survey & survey & online survey \\
\hline Data type & $\mathrm{RP}$ and $\mathrm{SP}$ & $\mathrm{RP}$ and $\mathrm{SP}$ & $\mathrm{RP}$ \\
\hline No. of interviews & 300 & 1835 & 218 \\
\hline Sample & $\begin{array}{l}\text { residents of San Francisco and } \\
\text { Oakland }\end{array}$ & $\begin{array}{l}\text { Dutch population over the age } \\
\text { of } 18\end{array}$ & $\begin{array}{c}\text { members of GoMore } \\
\text { (nationwide P2PCS network) }\end{array}$ \\
\hline Research question & $\begin{array}{l}\text { differences between B2C and } \\
\text { P2PCS adopters and barriers } \\
\text { against P2PCS }\end{array}$ & $\begin{array}{c}\text { differences between B2C and } \\
\text { P2PCS adopters }\end{array}$ & $\begin{array}{c}\text { mechanisms that influence the } \\
\text { use of P2PCS }\end{array}$ \\
\hline $\begin{array}{l}\text { Adopters' socio-economic } \\
\text { characteristics }\end{array}$ & $\begin{array}{c}\text { aged under } 40(+) \text {, frequent } \\
\text { car user }(-)\end{array}$ & $\begin{array}{l}\text { education (+), PT users (+), } \\
\text { environmental sensitivity (+) }\end{array}$ & $\begin{array}{l}\text { age } 30-34(+), \text { male }(+), \\
\text { education }(+)\end{array}$ \\
\hline \multirow{2}{*}{ Adopters' motives } & $\begin{array}{c}\text { renters: convenience }(+), \\
\text { vehicle variety }(+) \text {, economic } \\
\text { benefits }(+), \text { liability }(-), \\
\text { vehicle reliability }(-)\end{array}$ & $\begin{array}{l}\text { renters: already informally } \\
\text { provide their car to friends } \\
\quad \text { and family }\end{array}$ & $\begin{array}{l}\text { renters: more transport options } \\
(+), \text { cost savings }(+), \\
\text { environmental sustainability }(+)\end{array}$ \\
\hline & $\begin{array}{c}\text { car owners: extra income }(+), \\
\text { car used more efficiently }(+), \\
\text { liability }(-), \text { trust }(-)\end{array}$ & $\begin{array}{l}\text { car owners: trust more } \\
\text { important than extra income } \\
\text { P2P more cost-sensitive than } \\
\text { B2C but less public } \\
\text { transport-oriented }\end{array}$ & $\begin{array}{l}\text { car owners: extra income }(+), \\
\text { car used more efficiently }(+), \\
\text { environmental sustainability }(+)\end{array}$ \\
\hline
\end{tabular}

Note: $(+)$ means that the factor positively influences the adoption of P2PCS (-) means the opposite.

\subsection{Literature Analyzing the Supply}

Shaheen et al. [27] focused specifically on the supply side of the P2PCS market. In 2011, the authors interviewed 34 personal vehicle sharing operators and traditional carsharing providers operating in North America and France, insurance providers, and public policy authorities. They found four different types of P2PCS business models. In the fractional ownership model, individuals sub-lease or subscribe to a vehicle owned by a carsharing operator who purchases and manages the fleet. Subscribers and operators share income when the vehicle is rented to non-owners. In the hybrid P2P-traditional carsharing model, individuals join a carsharing organization including also private cars and the operator provides insurance for P2P vehicles. Operators keep a portion of the vehicle usage fee. In the standard P2P, individuals or members of a P2P company make temporarily available privately-owned vehicles for short-term (hourly or daily) or longer-term (multi-day) shared use. The P2P carsharing organization provides insurance during the access period and keeps a portion of the usage fee. Finally, in the P2P marketplace, individuals directly share the use of the vehicle via the Internet. Parties decide transaction terms including insurance, and disputes are subject to private resolution. According to the authors, the two most common barriers preventing the uptake of P2PCS were insurance coverage and fear of sharing personal vehicles. The primary motivations of car owners for joining a P2PCS were economic incentives and environmental benefits, besides having multiple automobiles. Dill et al. [28] studied whether participation as a car provider in the P2PCS system available in Portland impacted the driving time. They performed a survey in 2012 collecting in-depth interviews and car use data from 235 members of Getaround living in Portland. They found that the willingness to rent out the car is higher for young people, living with other adults in denser urban areas, having a higher income level and a higher level of education. They also found no overall reductions in driving from P2P vehicle owners, although they were able to detect different segments of the supply side of the market. A significant $39 \%$ of the sample reduced their driving by $10 \%$ or more, while $44 \%$ 
increased their driving by $10 \%$ or more. In addition, Wilhelms et al. [29] analyzed what factors favor P2PCS provision by car owners. They found that the most important ones are cost savings (reduction of fixed costs of car ownership-maintenance, taxes and insurance), extra income, allowing some users to live a car-free life, reducing the number of unused vehicles on the street and environmental sustainability. Barbour et al. [30] performed a web-based survey interviewing 644 members of a bike sharing program in Florida and the students and faculty of the University of South Florida with the aim of analyzing individuals' attitudes toward engaging in a P2PCS market as a car owner. They found that $14 \%$ of the sample would be willing to rent out their car and that the probability of willingness to provide the service decreases for females, being over 40 and having a higher income level (annual household income is more than USD 200,000).

Table 2. Papers analyzing only the supply side of the market.

\begin{tabular}{|c|c|c|c|c|}
\hline & Shaheen et al. 2012 [27] & Dill et al. 2019 [28] & Wilhelms et al. 2017 [29] & Barbour et al. 2020 [30] \\
\hline Country & USA and France & USA & Germany & USA \\
\hline Year & 2011 & 2012 & n.a. & 2018 \\
\hline Data collection & face-to-face interviews & $\begin{array}{l}\text { survey, vehicle use data, } \\
\text { in-depth interviews }\end{array}$ & $\begin{array}{l}\text { in-depth laddering } \\
\text { telephone interviews }\end{array}$ & web-based survey \\
\hline Data type & $\mathrm{RP}$ & $\mathrm{RP}$ & $\mathrm{RP}$ & $\mathrm{SP}$ \\
\hline No. of interviews & 34 & 235 & 20 & 644 \\
\hline Sample & $\begin{array}{c}\text { P2PCS and B2CCS } \\
\text { operators, insurance } \\
\text { providers, public policy } \\
\text { authorities }\end{array}$ & $\begin{array}{l}\text { members of Getaround } \\
\text { living in Portland }\end{array}$ & $\begin{array}{c}\text { members of a German } \\
\text { nationwide P2PCS } \\
\text { network }\end{array}$ & $\begin{array}{c}\text { members of bike sharing } \\
\text { in Florida and students } \\
\text { and faculty of the } \\
\text { University of South } \\
\text { Florida }\end{array}$ \\
\hline Research question & $\begin{array}{l}\text { business models, market } \\
\text { opportunities, service } \\
\text { barriers of P2PCS }\end{array}$ & $\begin{array}{l}\text { VMT reductions due to } \\
\text { participation in } \mathrm{P} 2 \mathrm{PCS}\end{array}$ & $\begin{array}{c}\text { factors favoring P2PCS } \\
\text { participation }\end{array}$ & $\begin{array}{l}\text { individuals' attitudes } \\
\text { toward renting out the car }\end{array}$ \\
\hline $\begin{array}{c}\text { Adopters' socio-economic } \\
\text { characteristics }\end{array}$ & $\begin{array}{l}\text { population density }(+) \text {, } \\
\text { multiple automobiles }(+)\end{array}$ & $\begin{array}{l}\text { age }(-) \text {, income }(+), \text { not } \\
\text { single }(+) \text {, education }(+), \\
\text { living in higher-density } \\
\text { areas }(+)\end{array}$ & n.a. & $\begin{array}{l}\text { aged under } 40(+) \text {, male } \\
(+) \text {, income }(-)\end{array}$ \\
\hline Adopters' motives & $\begin{array}{c}\text { extra income }(+) \\
\text { environmental } \\
\text { sustainability }(+), \text { liability } \\
(-) \text {, trust }(-)\end{array}$ & n.a. & $\begin{array}{l}\text { cost savings }(+), \text { extra } \\
\text { income }(+), \text { helping others } \\
(+), \text { environmental } \\
\text { sustainability }(+)\end{array}$ & n.a. \\
\hline
\end{tabular}

Note: $(+)$ means that the factor positively influences the adoption of P2PCS (-) means the opposite.

\subsection{Literature Analyzing the Demand}

Shaheen et al. [31] performed an online survey in 2014 with 1151 P2PCS members of RelayRides/Turo, Getaround and eGo carsharing, the most popular P2PCS platforms in the United States. They found that income level, educational level and being young and male positively influence the willingness to use P2PCS. They also found that P2PCS users increase the number of trips made overall, decrease taxi use and increase carpooling, walking and riding a bicycle. Co-benefits of P2PCS were increased accessibility and reduced car ownership. The authors concluded by emphasizing the importance of studying the potentialities of this form of CS in less-densely inhabited areas since it could increase general mobility and provide vehicle access to those who could not afford to purchase their own car. Prieto et al. [32] conducted an online survey in 2015 with a sample of 2733 individuals living in London, Madrid, Paris and Tokyo. The research aim was to analyze the impact of sociodemographic variables on carsharing behavior distinguishing between B2BCS and P2PCS. The authors found that being young, male, single and living in city centers favor P2PCS use and that $\mathrm{B} 2 \mathrm{C}$ and $\mathrm{P} 2 \mathrm{P}$ choices are driven by common latent preferences, although P2P potential demand is less segmented than B2C. Uteng et al. [33] compared the factors influencing the use of P2PCS and cooperative CS in Oslo (Norway). 
They interviewed 2856 members of two networks Nabobil (P2PCS) and Bilkollektivet (cooperative CS) administering a web-based questionnaire in 2017. They found that being male, aged 30-50, having a high educational level and living close to a public transport service stop/station (max $500 \mathrm{~m}$ ) increased CS use and that P2P is preferred to cooperative CS when relocating to a new residence, for cost savings and when parking access is critical. Finally, Wilhelms et al. [34] analyzed what factors favor P2PCS participation in Germany by interviewing 14 members of a nationwide P2P carsharing network via in-depth laddering interviews. They found that cost savings, flexibility (flexible pick-up and drop-off times and car owner response time), easy accessibility, variety of vehicles, ability to express status and trust (based on car owner profile, communication style and car equipment description) are the main and most important renters' motives for using the service.

Summarizing the evidence reported in the literature about the main motivations of car renters, they are mostly related to cost savings, convenience and the possibility of choosing among a large variety of car types. As for the socio-economic characteristics, car renters are generally young, male, have a high educational level and use public transport services or active transport modes (e.g., walking, riding a bicycle) more frequently.

Table 3. Papers analyzing only the demand side of the market.

\begin{tabular}{|c|c|c|c|c|}
\hline & Shaheen et al. 2019 [31] & Prieto et al. 2017 [32] & Uteng et al. 2019 [33] & Wilhelms et al. 2016 [34] \\
\hline Country/City & USA & $\begin{array}{c}\text { London, Madrid, Paris, } \\
\text { Tokyo }\end{array}$ & Oslo (Norway) & Germany \\
\hline Year & 2014 & 2015 & 2017 & na \\
\hline Data collection & online survey & online survey & web-based questionnaire & $\begin{array}{l}\text { in-depth laddering } \\
\text { telephone interviews }\end{array}$ \\
\hline Data type & $\mathrm{RP}$ & SP & $\mathrm{RP}$ & $\mathrm{RP}$ \\
\hline No. of interviews & 1151 & 2733 & 2856 & 14 \\
\hline Sample & $\begin{array}{c}\text { members of } \\
\text { RelayRides/Turo, } \\
\text { Getaround, eGo }\end{array}$ & $\begin{array}{c}\text { representative of car } \\
\text { owners (age, gender, } \\
\text { working status, location) }\end{array}$ & $\begin{array}{c}\text { members of Nabobil and } \\
\text { Bilkollektivet }\end{array}$ & $\begin{array}{c}\text { members of a German } \\
\text { nationwide P2PCS } \\
\text { network }\end{array}$ \\
\hline Research question & modal shift due to P2PCS & $\begin{array}{c}\text { impact of } \\
\text { sociodemographic } \\
\text { variables on P2PCS } \\
\text { behavior }\end{array}$ & $\begin{array}{c}\text { factors influencing P2P vs. } \\
\text { cooperative CS }\end{array}$ & $\begin{array}{l}\text { factors favoring P2PCS } \\
\text { participation }\end{array}$ \\
\hline $\begin{array}{c}\text { Adopters' socio-economic } \\
\text { characteristics }\end{array}$ & $\begin{array}{c}\text { income }(+) \text {, age } 25-34(+), \\
\text { male }(+), \text { education }(+), \\
\text { larger cities }(+), \text { n. trips } \\
(+), \text { taxi }(-) \text {, carpooling } \\
(+), \text { walk }(+), \text { bicycle }(+),\end{array}$ & $\begin{array}{l}\text { age }(-) \text {, male }(+) \text {, single } \\
(+) \text {, city center }(+)\end{array}$ & $\begin{array}{c}\text { age } 30-50(+), \text { male }(+), \\
\text { education }(+), \max 500 \mathrm{~m} \\
\text { to PT station }(+)\end{array}$ & n.a. \\
\hline Adopters' motives & $\begin{array}{l}\text { avoided vehicle } \\
\text { acquisitions }(+)\end{array}$ & $\begin{array}{l}\mathrm{B} 2 \mathrm{C} \text { and } \mathrm{P} 2 \mathrm{P} \text { choices are } \\
\text { driven by common latent } \\
\text { preferences }\end{array}$ & $\begin{array}{l}\text { relocating }(+), \text { cost savings } \\
(+) \text {, critical parking } \\
\text { access }(+)\end{array}$ & $\begin{array}{c}\text { cost savings }(+), \text { flexibility } \\
(+), \text { accessibility }(+), \\
\text { vehicle variety }(+), \\
\text { expressing status }(+), \\
\text { trust }(-)\end{array}$ \\
\hline
\end{tabular}

Note: (+) means that the factor positively influences the adoption of P2PCS (-) means the opposite.

\section{Supply and Demand of CS in Italy}

The CS market in Italy started about 20 years ago and has significantly changed over time, developing from its initial phase, characterized by extemporaneous local initiatives, to a consolidated mobility system offered in most of the largest Italian cities and in several medium ones. The largest operators providing CS services in Italy in 2019 were:

- Sharenow, with a fleet of 2815 vehicles available in Milan, Rome, Turin and Florence. Sharenow is a German company providing carsharing services in urban areas in Europe and formerly in North America. It is a joint venture of Daimler AG and BMW, which in 2018 merged their carsharing companies, car2go and DriveNow, respectively. 
It has over four million registered members and a fleet of over 14,000 vehicles in 18 cities across Europe.

- Enjoy, with a fleet of 2550 vehicles available in Milan, Rome, Turin, Florence, Bologna and Catania. Enjoy is an Italian company founded by ENI and renting only Fiat 500 cars provided by two long-term car rental companies, Leasys and Ald Automotive. Enjoy started its business in Milan in 2013, in 2014 it provided the service also in Rome and Florence, and it is now the second-largest carsharing company in Italy.

- Share'ngo, with a fleet of 1164 electric vehicles available in Milan, Rome, Florence and Modena. Share'ngo is an Italian-Chinese company that started operating in 2015 in Milan with the first fully electric, free-floating carsharing service. One year ago, the company was sold to a Dutch entrepreneur. Since then, both the fleet and the service were initially downgraded and then suspended, the main problems being the financial sustainability of the company and the high percentage of damaged cars.

At the end of December 2020, Blue Torino, a CS operator founded by Vincent Bolloré who started providing a station-based service in Turin in 2015 with a fleet of electric vehicles produced in Italy and 430 charging stations, also exited the market due to the high losses accumulated over time (EUR 15 million in 2019). A new operator, Leasys, a long-term car rental company, has acquired Blue Torino's license and charging network to provide the service with a fleet of 500 electric vehicles produced by FCA. The new operator is going to redesign the service, expanding the charging network to 550 stations and increasing the number of reserved parking spots to 560 .

The total number of shared vehicles in Italy has significantly increased since 2013 and was about 8250 in 2019 (Figure 2a). The free-floating fleet grew by 3.3\% between 2018 and 2019 reaching 7009 vehicles, while the number of electric vehicles used for free-floating services was 1586, slightly lower than the figure recorded in 2018 (1742). The station-based fleet grew by $6.9 \%$ compared to 2018 , and the share of electric vehicles increased from $33 \%$ in 2018 to $39 \%$ in 2019 . The environmental sustainability of the shared fleet is significantly higher than that of private vehicles. In fact, in 2019, the percentage of EURO 6 shared vehicles was $99 \%$, while the percentage of EURO 6 private vehicles was $24 \%$. The average age of the shared-vehicles fleet was 1.2 years in 2019, much lower than the average age of the private-vehicles fleet, which was 11.5 years.

The total number of members was slightly lower than 2.5 million in 2019, with a positive trend that has not decreased over time. Recently, the majority of CS operators have started offering both free-floating and station-based services so that most CS users in 2019 had the possibility to choose between both service types using the same membership. The higher flexibility guaranteed by this opportunity increased the number of members by $30 \%$ between 2018 and 2019 (Figure 2b).

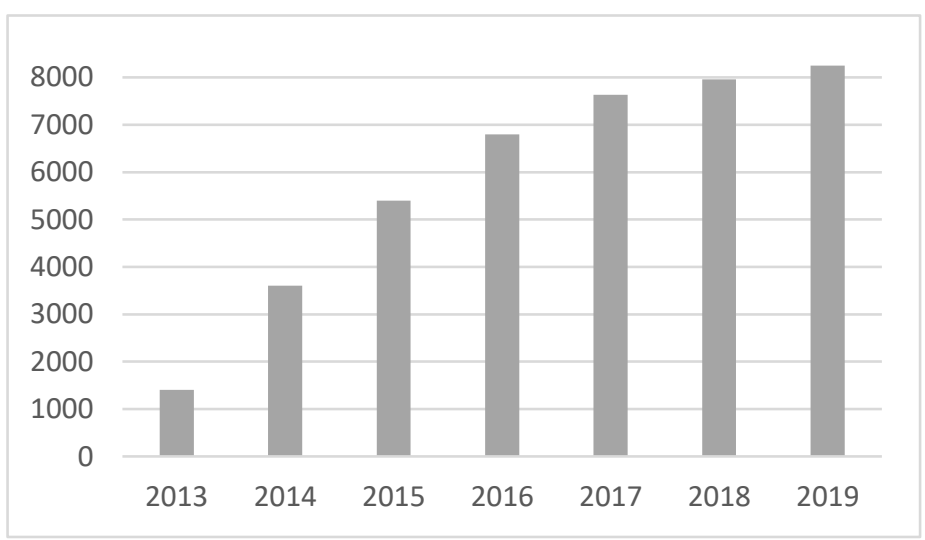

(a)

Figure 2. Cont. 


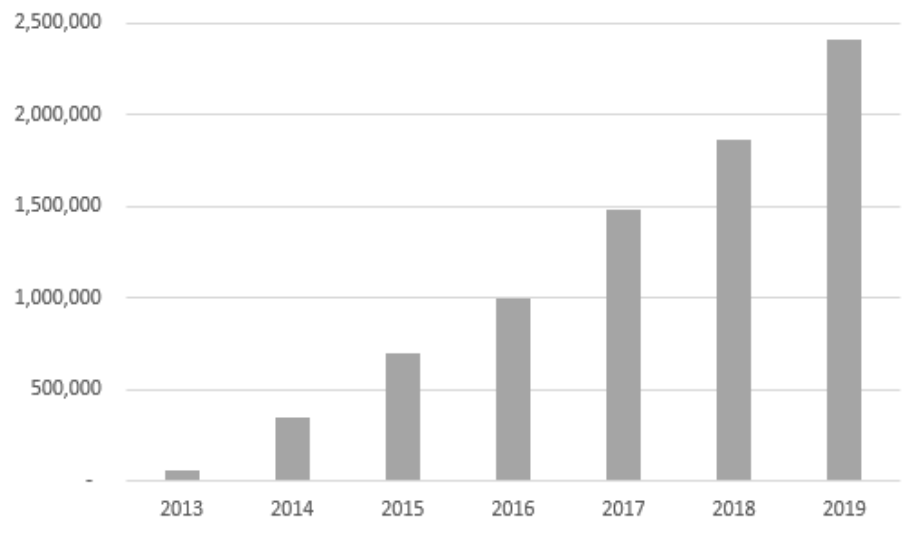

(b)

Figure 2. (a) Number of shared vehicles; (b) Number of members.

The total number of rentals was 12.25 million in 2019 (Figure 3a). Free-floating rentals were about 12 million, in line with the figure recorded in the previous year. Milan, Rome and Turin, which are the largest Italian cities, recorded the highest number of rentals, 6.2 million, 3.2 million and 1.7 million, respectively. Station-based rentals had always been smaller than free-floating, however, in 2019, they grew by $34 \%$ compared to the previous year. Station-based services proved an effective mobility option, especially in medium-size urban areas.

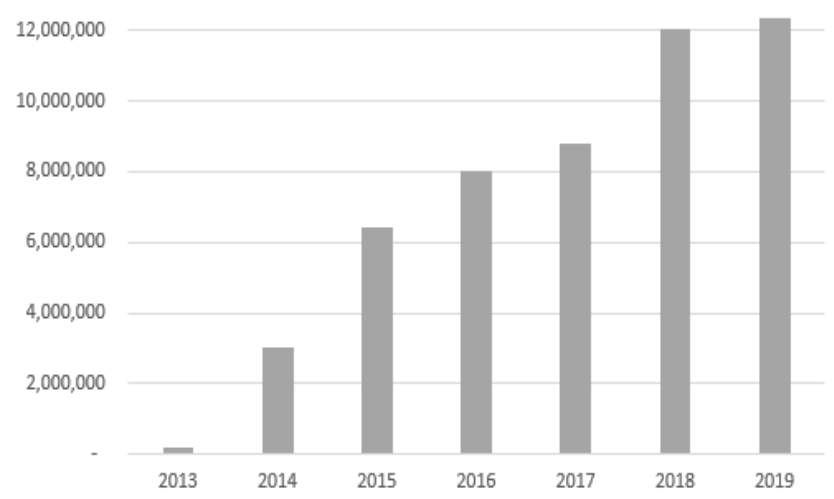

(a)

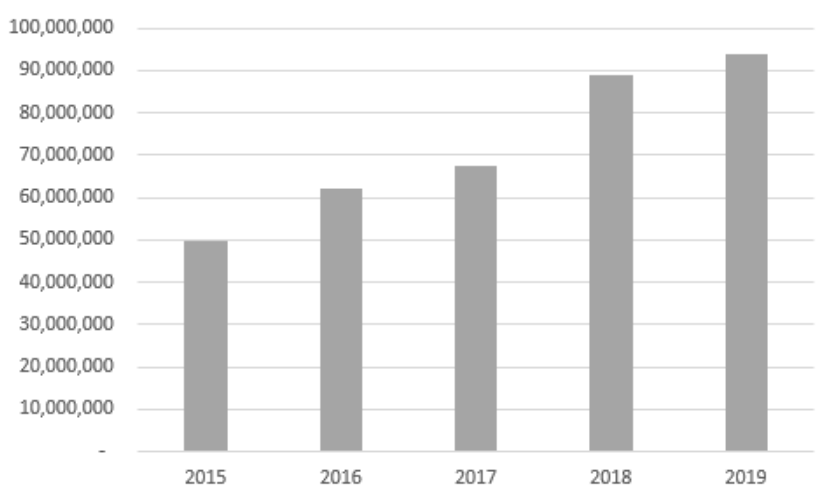

(b)

Figure 3. (a) Number of rentals; (b) Number of km traveled.

The total number of kilometers traveled significantly increased in 2019, reaching 94 million (Figure $3 b$ ). The distance traveled with free-floating services, which on average 
was $7.4 \mathrm{~km}$ per rental, increased by $9.9 \%$, about three times the growth of the rentals, improving the financial sustainability of this type of CS. The opposite trend was recorded for station-based services, with an average distance traveled of $25.2 \mathrm{~km}$, decreasing by $18 \%$ compared to 2018. More than half of the free-floating rentals (63\%) lasted less than $20 \mathrm{~min}$, while the station-based ones lasted much longer, with an average travel time of $178 \mathrm{~min}$. The average number of times a car was rented per day through a free-floating service was four, in line with the value recorded in the previous year. The average rental time of a station-based car over the $24 \mathrm{~h}$ was $13 \%$ which is also in line with the value recorded in the previous year.

Although the Italian carsharing market is characterized by remarkably positive trends with respect to members, rentals and kilometers traveled, the Share'ngo and the Blue Torino business cases are emblematic of how the scalability of the service is risky and difficult, even more so if the market to be served is made of less-densely inhabited areas. Indeed, although currently the CS services are mostly offered in large cities, they would be even more useful in rural areas where public transport services are less frequent if not completely lacking. In these areas, P2PCS might be more successful and sustainable than B2CCS. In Italy, however, P2PCS is a new business model in the initial phase of its life cycle. It started in 2018 and is currently offered by two platforms, Auting and Genial Move, with a total of 17,000 members, 1600 cars and 4150 rents.

\section{Potential Demand for P2PCS in Italy}

To study the potential demand for P2PCS in Italy and more specifically in less-densely inhabited regions, we carried out a survey via face-to-face interviews in Friuli-Venezia Giulia, a northeastern region bordering Austria and Slovenia.

\subsection{Method}

In order to collect the data, we used a four-part structured questionnaire. In the first part, we asked about the interviewee's mobility habits (frequency and means of transport used on weekdays and weekdays). In the second part, we asked whether the interviewee would be willing to use a CSP2P service instead of the transport mode currently used. In the third part, we asked which factors would favor and which factors would prevent the use of CSP2P by the interviewee. We proposed the following items asking to state which ones would be a source of discomfort in using the service:

- Damaging the car;

- Car might be stolen while rented;

- Need of cleaning the car;

- Renting a soiled car;

- Being responsible for the owner's belongings;

- Need of refueling the car;

- Facing time constraints.

We also asked what they would like to know in order to rent a car, and we proposed the following items:

- The owner's profile with the users' opinion;

- The vehicle profile with the users' judgment;

- How to check fuel consumption and mileage;

- If there is a daily mileage limit;

- How far in advance should the vehicle be booked;

- If the car is clean before it is delivered;

- If the car can be returned to a place other than where it was picked up;

- Who to call or how to replace the car in case of breakdowns.

Additionally, we asked why they would be willing to rent a car, and the respondents could choose among the following items:

- Owning a car is too expensive; 
- Maintaining a car takes too long;

- I don't have a garage;

- Owning a garage is too expensive;

- Finding parking is difficult;

- I could choose among different types of vehicles;

- It is more convenient than the bus;

- It is less expensive than taxis.

Finally, in the fourth part, we collected data about the socio-economic characteristics of the respondent.

We carried out 200 face-to-face interviews in December 2019 in gathering places such as squares, shopping centers and transport network hubs (railway stations, bus stations, bus stops) of the city and provinces of Trieste (38\%) and Udine (62\%). In the following sections, we provide a descriptive evaluation of the data collected.

\subsection{The Sample}

The sample, equally divided between males and females, included 200 individuals: $9 \%$ were aged between 18 and 24, 35\% between 25 and $44,39 \%$ between 45 and 64 , and $17 \%$ were over 64 years old. Most of the individuals interviewed worked as employees (47\%) or self-employed ( $9 \%$ ), students represented $19 \%$ of the sample, retired and housewives accounted for $18 \%$ of the sample, while the unemployed amounted to $7 \%$ of the sample. With respect to the educational level, $48 \%$ of the respondents had a university degree, $35 \%$ had a high school diploma, while $18 \%$ had a lower middle school diploma (Figure 4).

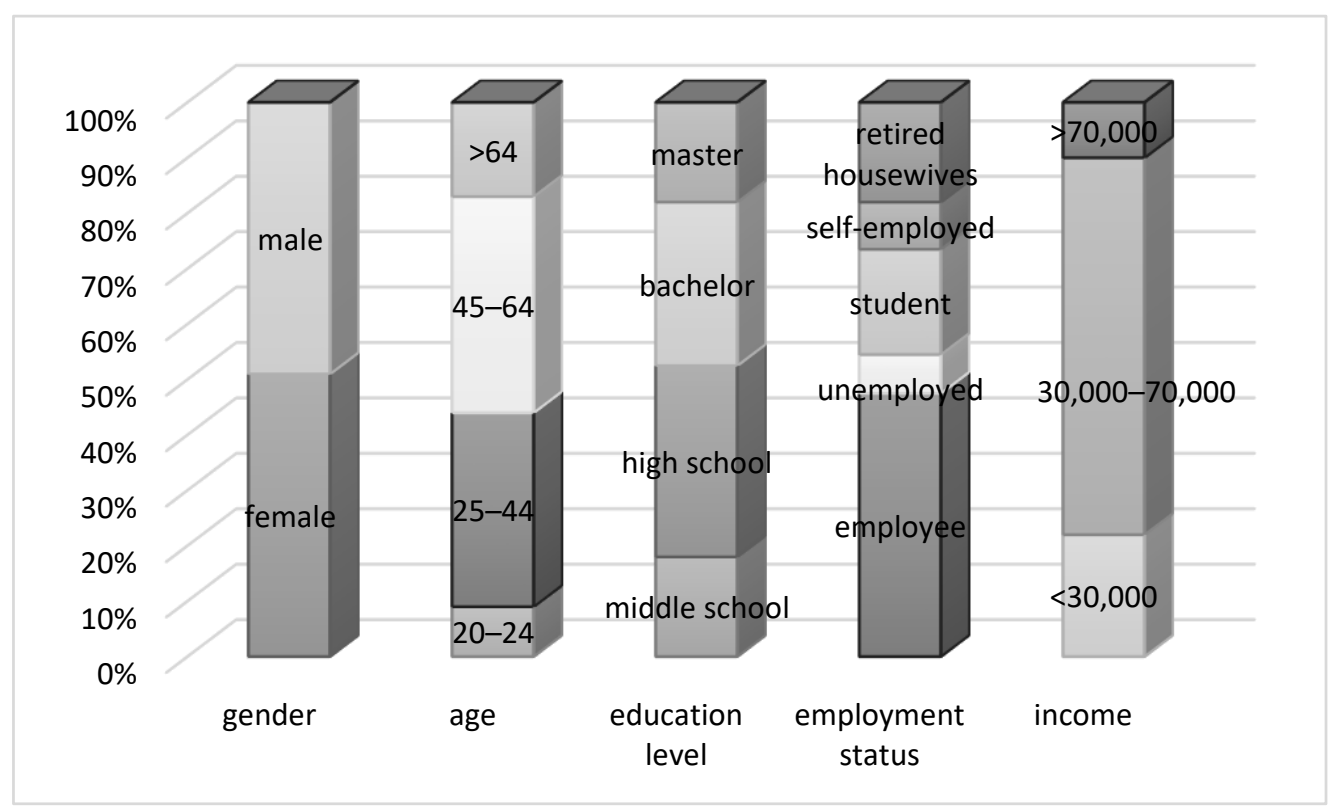

Figure 4. Socio-economic characteristics of the sample.

All respondents had a driving license. On average, the number of cars available for each member of the respondents' household having a driving license was 0.5 . The car was the transport mode most frequently used by $49 \%$ of the sample during weekdays and by $70 \%$ of the sample during weekends. The second most frequently used transport mode was the bus, used by $36 \%$ of respondents on weekdays, but only by $21 \%$ of the sample during weekends (Figure 5). 


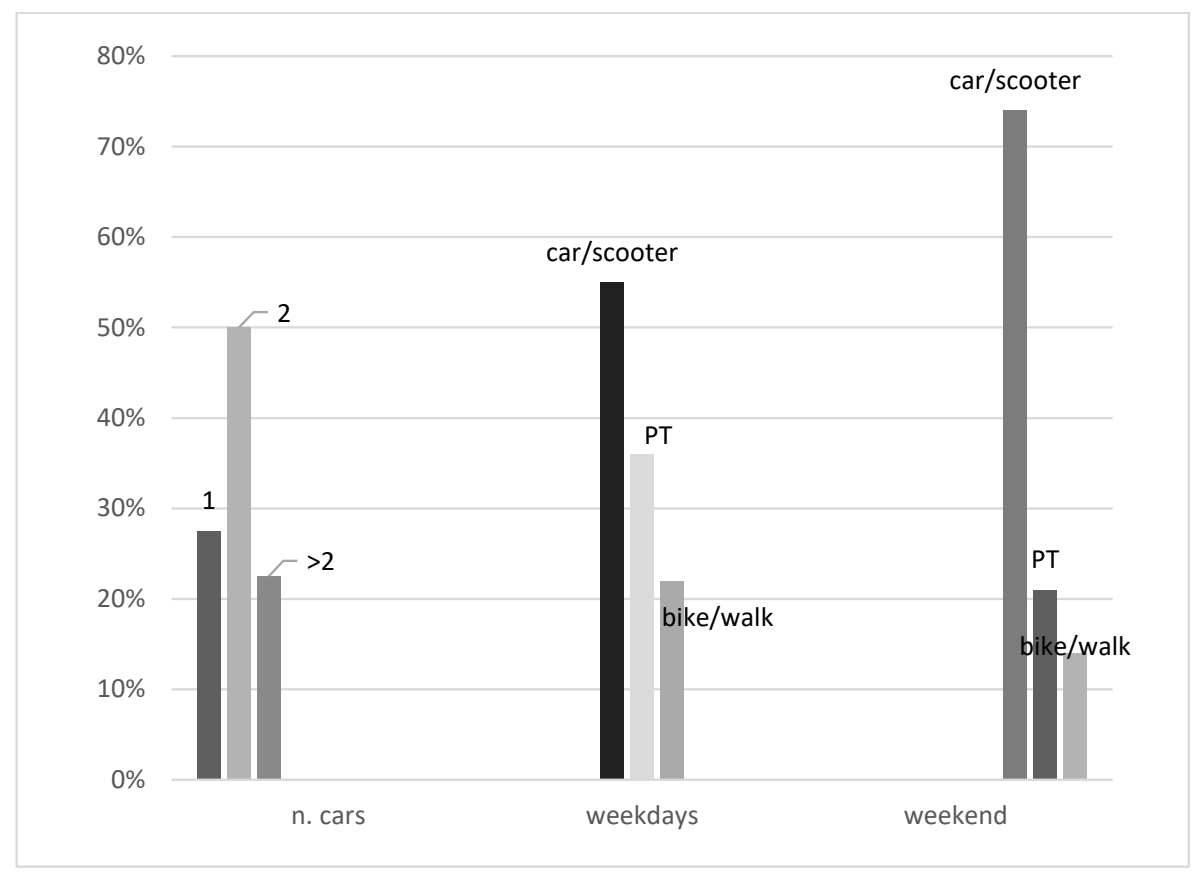

Figure 5. Mobility habits of the sample.

\subsection{Results}

Half of the sample knew what a CS service is. CS knowledge is significantly influenced by respondents' age, educational level, gender and occupational status. The majority of the respondents aged between 25 and 44 (77\%) were familiar with this form of mobility, followed by individuals aged between 18 and 24 (61\%). A large percentage (65\%) of interviewees with a bachelor's or a master's degree knew what a CS is, while only 35\% of those with a lower educational qualification were familiar with this form of mobility. The majority of the students interviewed $(76 \%)$ knew what a CS service is, while almost none of the interviewed who were retired were familiar with it (Table 4). None of the respondents was aware of what a P2PCS is and of the fact that it is already possible to use the service either as a car owner or as a car renter through two Italian platforms.

Table 4. Percentage of individuals knowing what a carsharing (CS) service is CS by socio-economic factor.

\begin{tabular}{|c|c|c|c|}
\hline Age * & Education * & Gender * & $\underset{*}{\text { Occupational Status }}$ \\
\hline $18-24(61 \%)$ & Middle school (3\%) & Male $(58 \%)$ & Student $(76 \%)$ \\
\hline $25-44(77 \%)$ & High school (52\%) & Female $(42 \%)$ & Employed (52\%) \\
\hline $45-64(42 \%)$ & Bachelor's/Master's (65\%) & & Unemployed $(79 \%)$ \\
\hline $65-(3 \%)$ & & & Retired (3\%) \\
\hline
\end{tabular}

Note: $\left({ }^{*}\right)$ chi-squared test statistically significant at the $1 \%$ level.

One-fourth of the sample answered that they would use CSP2P if available. This potential penetration rate is larger than the threshold estimated by Hampshire et al. [35] for a successful and financially sustainable P2PCS. According to the authors, the threshold is equal to 10 potential members living within a $0.4 \mathrm{~km}$ radius of each single car location, corresponding to $0.8 \%$ of the population in an area with 10 residents $/$ acre $\left(40\right.$ residents $\left./ \mathrm{km}^{2}\right)$. Since the population density of Friuli-Venezia Giulia is $150 / \mathrm{km}^{2}$, a potential demand of $25 \%$ of the population is well above the minimum percentage needed for the provision of a viable and sustainable P2PCS system. 
The respondents most likely to use the service were women (differently from references [26,31-33]), having a master's degree (similarly to references [25,26,31-33]), aged between 25 and 44 (consistently with references [24,26,31-33]), with strong environmental sensitivity (in line with reference [26]), frequently using public transport services (similarly to references $[25,33]$ ) during weekdays (Table 5). Moreover, the differences in the percentage of individuals willing to use P2PCS by each socio-economic factor (gender, education level, age, environmental sensitivity and mobility habit) are statistically significant according to the chi-squared test we performed. However, the descriptive approach we used to report the data only depicts the status quo and does not allow us to interpret these differences as cause-effect relationships between the socio-economic factors analyzed and the willingness to use P2PCS services. Nevertheless, these results are largely consistent with the evidence reported in the literature on the most important socio-economic characteristics influencing the willingness to use CS and P2PCS with the exception of gender since, according to the evidence reported in the literature, males are typically more favorable than female toward P2PCS adoption.

Table 5. Percentage of individuals willing to use peer-to-peer carsharing (P2PCS) by socio-economic factor.

\begin{tabular}{ccccc}
\hline Gender** & Education* & Age & Environmental Sensitivity & Public Transport Use * \\
\hline Male (19\%) & Middle school (3\%) & $18-24(22 \%)$ & $\begin{array}{c}\text { Took part in environmental } \\
\text { protests (38\%) }\end{array}$ & $\begin{array}{c}\text { Not using PT services } \\
(15 \%)\end{array}$ \\
\hline Female (31\%) & High school (23\%) & $25-44(43 \%)$ & $\begin{array}{c}\text { Never took part in } \\
\text { environmental protests (23\%) }\end{array}$ & $\begin{array}{c}\text { Less than } 4 \text { round trips } \\
\text { per week (10\%) }\end{array}$ \\
\hline & Bachelor's/Master's (35\%) & $45-64(21 \%)$ & $\begin{array}{c}\text { More than 4 round } \\
\text { trips per week (55\%) }\end{array}$ \\
\hline
\end{tabular}

Note: chi-squared test statistically significant at the $1 \%$ level $\left({ }^{*}\right)$; at the $5 \%$ level $\left({ }^{* *}\right)$; at the $10 \%$ level $\left({ }^{* * *}\right)$.

The majority of the respondents in favor of P2PCS stated that they would be willing to pay EUR 5 per hour to use it (82\%), 10\% would be willing to pay less than EUR 5, and $8 \%$ would be willing to pay EUR 10 per hour. The values stated by the majority of the respondents are smaller than the rent fees charged for B2CCS services in Italy (EUR 11.4/h, https://www.share-now.com/it/it/), however, P2PCS are generally cheaper than B2CCS (about EUR 1.6/h), with EUR 40 as the average daily fee (based on data published by Auting at https://auting.it/), and they are also smaller than the willingness to pay of the sample.

The type of vehicles that they would most likely rent is city cars (58\% of the segment willing to use P2PCS), followed by family cars (30\% of the segment willing to use P2PCS).

The P2PCS service would be mainly used during weekdays as an alternative to the private car or the bus (Table 6). Individuals traveling mostly by car would substitute on average $62 \%$ of their weekday trips and only $3 \%$ of their weekend trips with P2PCS. Individuals traveling mostly by bus would replace on average $80 \%$ of their weekday trips and $18 \%$ of their weekend trips with P2PCS. People who move on foot would substitute $34 \%$ of trips on weekdays with P2PCS. Journeys made by motorcycle, scooter, train or bicycle would not be replaced by CS.

Table 6. Percentage of individuals willing to use P2PCS by mobility habits.

\begin{tabular}{cccc}
\hline Car & Bus & Train & Walk \\
\hline Weekdays (95\%) & Weekdays (100\%) & Weekdays (100\%) & Weekdays (50\%) \\
Weekends (3\%) & Weekends (30\%) & Weekends (0\%) & Weekends (0\%) \\
\hline
\end{tabular}


The reasons most frequently stated for willingness to use P2PCS were that it is more convenient and flexible compared to public transport (in line with references [24,34]). The fact that there is no need to own a garage or to look for parking once having returned home (consistently with reference [33]) and the greater cost-effectiveness of P2PCS compared to owing a car (similarly to references $[24,26,31,33,34]$ ) are also deemed important factors (Table 7, first column).

Table 7. Latent beliefs and psychological barriers of individuals willing to rent a car.

\begin{tabular}{|c|c|c|}
\hline Motives in Favor & Concerns & Critical Factors \\
\hline better than bus $(98 \%)$ & time constraints $(96 \%)$ & vehicle profile (100\%) \\
\hline no parking difficulties (94\%) & refueling the car $(62 \%)$ & $\begin{array}{l}\text { if it is possible to return to a place other than where it was } \\
\text { picked up }(100 \%)\end{array}$ \\
\hline cost savings $(86 \%)$ & damaging the car $(50 \%)$ & who to call for assistance $(96 \%)$ \\
\hline no need for garage $(36 \%)$ & owner's belongings (26\%) & daily mileage limit (92\%) \\
\hline better than taxi $(36 \%)$ & renting a soiled car $(12 \%)$ & how to check fuel consumption $(72 \%)$ \\
\hline time saving $(36 \%)$ & car stolen while rented $(6 \%)$ & how far in advance for booking (72\%) \\
\hline garage expensive $(18 \%)$ & cleaning the car $(2 \%)$ & cleaning conditions (42\%) \\
\hline variety of vehicles ( $2 \%)$ & & owner's profile $(26 \%)$ \\
\hline
\end{tabular}

The most frequently cited concerns related to the use of the service were the time constraints in the collection and return of the vehicle and the need to refuel the vehicle before returning it (Table 7 , second column).

Critical factors for willingness to use the service were the availability of the vehicle description and users' opinion about the characteristics of the vehicle. In addition, the possibility of returning the car to a place other than the one where it was picked up was cited as a very important condition in order to be willing to use the service. Knowing in advance who to contact in case of malfunctions, unlimited daily mileage, transparent methods of checking fuel consumption and how much in advance it is necessary to book the vehicle were also relevant factors influencing the willingness to use the service (Table 7 , third column).

The main reasons why $75 \%$ of the sample stated that they would not use the service were the time constraints regarding the place and time of getting and returning the car and the need to refuel the vehicle before returning it (Table 8, first column).

Table 8. Latent beliefs and psychological barriers of individuals not willing to rent a car.

\begin{tabular}{cc} 
Concerns & Critical Factors \\
\hline time constraints $(95 \%)$ & no need to book in advance $(98 \%)$ \\
\hline refueling the car $(61 \%)$ & who to call for assistance $(96 \%)$ \\
\hline damaging the car $(52 \%)$ & $\begin{array}{c}\text { if it is possible to return to a place other than } \\
\text { where it was taken }(94 \%)\end{array}$ \\
\hline renting a car never driven before $(49 \%)$ & daily mileage limit $(92 \%)$ \\
\hline car malfunctioning $(35 \%)$ & how to check fuel consumption $(90 \%)$ \\
\hline owner's belongings $(24 \%)$ & owner's profile $(83 \%)$ \\
\hline renting a soiled car $(11 \%)$ & \\
\hline car stolen while rented $(7 \%)$ & \\
\hline cleaning the car $(2 \%)$ & \\
\hline
\end{tabular}

However, $53 \%$ of those who stated that they would not use the service said that under certain conditions, they would change their mind and they would actually rent a car. The 
conditions deemed most relevant were the possibility of not having to book the vehicle in advance, the guarantee of assistance in case of vehicle malfunctions and the possibility of returning the vehicle to a place other than the one where it was picked up. Additional critical factors were unlimited daily mileage and information on how fuel consumption is measured (Table 8, second column).

\section{Discussion and Conclusions}

\subsection{Discussion and Contribution}

Internet-based exchange markets are shifting consumers from owning resources to sharing their consumption. Collaborative consumption is spreading also within the transport sector where carsharing, either in the business-to-consumer setting or in the peer-topeer setting, is increasing its market share compared to other mobility systems.

The CS market in Italy started about 20 years ago and is now a consolidated mobility system provided in most of the largest Italian cities and in several medium ones. The Italian CS market, in fact, is characterized by remarkably positive trends with respect to the number of members, rentals and kilometers traveled, free-floating being by far the most diffused CS type if compared to the station-based one. P2PCS, instead, is offered only by two platforms and is seldom known and used, especially in rural areas where it could represent a viable alternative to the ownership and use of private vehicles and to public transport services.

Our research describes the current status of the Italian P2PCS perception distinguishing between the motives of individuals willing to use the services from the motives of individuals not willing to use it. Moreover, we investigated the potentialities of this innovative form of CS in a less densely inhabited area, the Friuli-Venezia Giulia region.

According to our results, $25 \%$ of the individuals we interviewed would be willing to use a P2PCS service if available, confirming its good potentialities also in less inhabited regions. We found that the willingness to use CS is significantly influenced by gender, level of education, age, environmental sensitivity and frequency of public transport service use. The motives for willingness to rent a car are mainly related to convenience and cost savings compared to using public transport services and owning a car, respectively. However, the lack of trust among individuals is one of the most critical issues in personal vehicle sharing. As stated by Shaheen et al. [27], it requires a user rating and feedback system, operator screening and selection and social networking besides vehicle quality assurance and responsive customer service. The evidence reported in the literature is confirmed by our results, however, the sources of concern in using P2PCS expressed by the sample we interviewed are also related to time constraints and coordination issues, assistance in case of malfunctioning and liability.

Technology could play a crucial role in overcoming these problems since unattended access promotes user safety and reduces potential access issues caused by a lack of coordination among individuals. Technologically advanced platforms could also avoid the need of booking the car in advance. Moreover, they could enable direct interaction between renters and car owners allowing them to reach an agreement not only on the place where to return the car, a critical factor according to our results, but also on other features of the service deemed important by the demand side of the market (daily mileage limit, refueling, cleaning conditions).

However, according to our analysis, the largest obstacle for the development of this form of CS in Italy is the lack of awareness of the existence of the service. Indeed, although $50 \%$ of the sample knew what a CS service is, none of the individuals we interviewed knew what a P2PCS is, and nobody was aware that there are already two platforms providing this service in Italy.

\subsection{Management and Policy Implications}

On the basis of our results, we conclude that the existing P2PCS platforms should intensify the promotion of their services; to this aim, they should use a large spectrum of 
different channels, including social media. Moreover, in order to increase their visibility, they could engage in public-private partnerships with local administrators and public transport providers. They should provide a more detailed description of the characteristics of the service, informing not only on how the service works but also on how both car owners and renters could benefit from sharing a private vehicle, emphasizing also the favorable motives stated by our sample. Moreover, in order to launch and strengthen the service in less densely inhabited areas, they should at least temporally grant special discounts to new members living in rural areas, applying for public subsidies in light of the higher accessibility level guaranteed due to the service offered.

Local administrators could support the uptake of this new form of CS providing P2PCS users with parking discounts, dedicated parking spots and access permits to urban limited traffic zones. These policies could be further fine-tuned to support the use of P2PCS for trips originated from less densely inhabited areas that are not served by public transport services. Moreover, they could be differentiated according to the environmental impact of the shared vehicles. Supporting P2PCS as a supplement to public transport would create a more flexible and efficient transport system instead of a system where modes are competing against each other.

Financial constraints and increasing mobility demand require public administrators to replace the public service monopoly with multi-actor collaboration across municipal borders and private market domains. Integrating different transport modes by including P2PCS in multimodal hubs via multimodal platforms (MaaS) has the potentiality of increasing the accessibility of rural areas, reducing the financial burden of local public transport, using more efficiently the private fleet and the road network and reducing the environmental impact of the transport sector. Planning authorities and other actors in the public domain play a crucial role in achieving all these aims. They need to monitor the social and environmental impact of this new form of mobility and drive its uptake so that it continues lowering the overall car use and ownership while fostering accessibility and environmental sustainability.

\subsection{Limitation and Future Work}

The main limitation of our research is the small size of the sample we interviewed. In order to overcome this limitation, we will collect additional interviews and we will focus on members of the P2PCS platforms offering the service in Italy. Future work should also detect to what extent P2PCS enhances accessibility and social inclusion and whether it is effective in reducing the number of cars within urban areas. We will also try to understand why in our case study females are more in favor of P2PCS than males since this result is markedly different from the evidence reported in the literature. Finally, we will analyze the impact that the COVID-19 pandemic has produced in the CS market since in Italy it has dramatically reduced the demand for CS services.

Funding: This research received no external funding.

Institutional Review Board Statement: Not applicable.

Informed Consent Statement: Not applicable.

Data Availability Statement: The data presented in this study are available on request from the corresponding author. The data are not publicly available due to privacy.

Conflicts of Interest: The author declares no conflict of interest.

\section{References}

1. COM. Comunicazione della Commissione al Parlamento Europeo, al Consiglio, al Comitato Economico e Sociale Europeo e al Comitato delle Regioni: Un Programma “Aria Pulita” per l’Europa, 918. 2013. Available online: https://ec.europa.eu/ transparency/regdoc/rep/1/2013/IT/1-2013-918-IT-F1-1.Pdf (accessed on 13 December 2020).

2. Sistema Nazionale per la Protezione dell'Ambiente. La Qualità Dell'aria in Italia. Edizione 2020, Report 17. 2020. Available online: https:/ / www.snpambiente.it/2020/12/01/la-qualita-dellaria-in-italia-edizione-2020/ (accessed on 13 December 2020). 
3. Istituto Superiore di Formazione e Ricerca per i Trasporti, ISFORT. La Mobilità in Italia tra la Gestione del Presente e le Strategie per il Future $17^{\circ}$ Rapporto Sulla Mobilità Degli Italiani. 2020. Available online: https://www.isfort.it/progetti/17-rapportoaudimob-sulla-mobilita-degli-italiani/ (accessed on 18 December 2020).

4. Clewlow, R.R. Carsharing and sustainable travel behavior: Results from the San Francisco Bay Area. Transp. Policy 2016, 51, 158-164. [CrossRef]

5. Flemming, G.; Nobis, C. The impact of carsharing on car ownership in German cities. Transp. Res. Procedia 2016, 19, 215-224.

6. Le Vine, S.; Polak, J. The impact of free-floating carsharing on car ownership: Early-stage findings from London. Transp. Policy 2017, 75, 119-127. [CrossRef]

7. Nijland, H.; van Meerkerk, J. Mobility and environmental impacts of car sharing in the Netherlands. Environ. Innov. Soc. Transit. 2017, 23, 84-91. [CrossRef]

8. Becker, H.; Ciari, F.; Axhausen, K.W. Measuring the car ownership impact of free-floating car-sharing-A case study in Basel, Switzerland. Transp. Res. Part D Transp. Environ. 2018, 65, 51-62. [CrossRef]

9. Liao, F.; Molin, E.; Timmermans, H.; van Wee, B. Carsharing: The impact of system characteristics on its potential to replace private car trips and reduce car ownership. Transportation 2018, 47, 935-970. [CrossRef]

10. Kim, J.; Rasouli, S.; Timmermans, H.J. The effects of activity-travel context and individual attitudes on car-sharing decisions under travel time uncertainty: A hybrid choice modeling approach. Transp. Res. Part D Transp. Environ. 2017, 56, 189-202. [CrossRef]

11. Shaheen, S.; Cohen, A.; Farrar, E. Carsharing's impact and future. Adv. Transp. Policy Plan. 2019, 4, 87-120.

12. Kent, J.L. Carsharing as active transport: What are the potential health benefits? J. Transp. Health 2014, 1, 54-62. [CrossRef]

13. Namazu, M.; Dowlatabadi, H. Vehicle ownership reduction: A comparison of one-way and two-way carsharing systems. Transp. Policy 2018, 64, 38-50. [CrossRef]

14. Luna, T.F.; Uriona-Maldonado, M.; Silva, M.E.; Vaz, C.R. The influence of e-carsharing schemes on electric vehicle adoption and carbon emissions: An emerging economy study. Transp. Res. Part D Transp. Environ. 2020, 79, 102226. [CrossRef]

15. Baptista, P.; Melo, S.; Rolim, C. Energy, environmental and mobility impacts of car-sharing systems. Empirical results from Lisbon, Portugal. Procedia-Soc. Behav. Sci. 2014, 111, 28-37. [CrossRef]

16. Chen, T.D.; Kockelman, K.M. Carsharing's life-cycle impacts on energy use and greenhouse gas emissions. Transp. Res. Part D Transp. Environ. 2016, 47, 276-284. [CrossRef]

17. Lang, B.; Dolan, R.; Kemper, J.; Northey, G. Prosumers in times of crisis: Definition, archetypes and implications. J. Serv. Manag. 2020. [CrossRef]

18. Bruno, B.; Faggini, M. Sharing economy: For an economic taxonomy. Int. J. Econ. Financ. 2017, 9, 174-178. [CrossRef]

19. Bardhi, F.; Eckhardt, G.M. Access-based consumption: The case of car sharing. J. Consum. Res. 2012, 39, 881-898. [CrossRef]

20. Hamari, J.; Sjöklint, M.; Ukkonen, A. The sharing economy: Why people participate in collaborative consumption. J. Assoc. Inf. Sci. Technol. 2016, 67, 2047-2059. [CrossRef]

21. Page, W.H.; Lopatka, J.E. Network externalities. Encycl. Law Econ. 1999, 760, 952-980.

22. Eisenmann, T.; Parker, G.; Van Alstyne, M.W. Strategies for two-sided markets. Harv. Bus. Rev. 2006, 84, 92.

23. Cohen, B.; Kietzmann, J. Ride on! Mobility business models for the sharing economy. Organ. Environ. 2014, 27, 279-296. [CrossRef]

24. Ballús-Armet, I.; Shaheen, S.A.; Clonts, K.; Weinzimmer, D. Peer-to-peer carsharing: Exploring public perception and market characteristics in the San Francisco Bay area, California. Transp. Res. Rec. 2014, 2416, 27-36. [CrossRef]

25. Münzel, K.; Piscicelli, L.; Boon, W.; Frenken, K. Different business models-different users? Uncovering the motives and characteristics of business-to-consumer and peer-to-peer carsharing adopters in The Netherlands. Transp. Res. Part D Transp. Environ. 2019, 73, 276-306. [CrossRef]

26. Gaarsdal, D.; Collin, H.; Roelof, J.; Sønderkær, J.; Emely, K.; Madsen, K.; Winther, S. Peer-to-Peer Car Sharing-Transitional Pathway or Gateway Drug? Aalborg University 2017. Available online: http://danskedelebiler.dk/wp-content/uploads/2018/0 3/07.07.2017.Car-Sharing.pdf (accessed on 1 December 2020).

27. Shaheen, S.A.; Mallery, M.A.; Kingsley, K.J. Personal vehicle sharing services in North America. Res. Transp. Bus. Manag. 2012, 3, 71-81. [CrossRef]

28. Dill, J.; McNeil, N.; Howland, S. Effects of peer-to-peer carsharing on vehicle owners' travel behavior. Transp. Res. Part C Emerg. Technol. 2019, 101, 70-78. [CrossRef]

29. Wilhelms, M.P.; Merfeld, K.; Henkel, S. Who Uses Peer-to-Peer Car Sharing Anyhow? Insights into Motives for Peer-to-Peer Car Sharing Usage Summer AMA Proceedings. 2016. Available online: http://toc.proceedings.com/34223webtoc.pdf (accessed on 1 December 2020).

30. Barbour, N.; Zhang, Y.; Mannering, F. Individuals' willingness to rent their personal vehicle to others: An exploratory assessment of peer-to-peer carsharing. Transp. Res. Interdiscip. Perspect. 2020, 5, 100138. [CrossRef]

31. Shaheen, S.; Martin, E.; Hoffman-Stapleton, M. Shared mobility and urban form impacts: A case study of peer-to-peer (P2P) carsharing in the US. J. Urban Des. 2019, 1-18. [CrossRef]

32. Prieto, M.; Baltas, G.; Stan, V. Car sharing adoption intention in urban areas: What are the key sociodemographic drivers? Transp. Res. Part A Policy Pract. 2017, 101, 218-227. [CrossRef] 
33. Uteng, T.P.; Julsrud, T.E.; George, C. The role of life events and context in type of car share uptake: Comparing users of peer-to-peer and cooperative programs in Oslo, Norway. Transp. Res. Part D Transp. Environ. 2019, 71, 186-206. [CrossRef]

34. Wilhelms, M.P.; Henkel, S.; Falk, T. To earn is not enough: A means-end analysis to uncover peer-providers' participation motives in peer-to-peer carsharing. Technol. Forecast. Soc. Chang. 2017, 125, 38-47. [CrossRef]

35. Hampshire, R.C.; Gaites, C. Peer-to-peer carsharing: Market analysis and potential growth. Transp. Res. Rec. 2011, 2217, 119-126. [CrossRef] 